\title{
Hubungan Angiogenesis dengan Gambaran Morfologi dan Klinis Kanker Payudara pada Kultur Jaringan
}

\author{
Darwito*, Sonar S. Panigoro*, Muchlis Ramli
}

ARTIKEI

ASLI

\begin{abstract}
Abstrak
Pendahuluan : Seperti tumor padat lainnya kanker payudara dapat tumbuh dan bermetastasis bila memperoleh oksigen dan nutrisi yang cukup. Tanpa adanya suplai darah yang menyediakan oksigen dan nutrisi maka tumor akan diam atau bahkan mati. Suplai darah bisa terjadi apabila sel tumor mampu membentuk pembuluh darah baru, yang disebut angiogenesis, yang merupakan faktor terpenting agar sel kanker itu dapat tumbuh dan melakukan metastasis.

Metode : Penelitian ini menggunakan studi prospektif cross sectional dengan melakukan kultur jaringan kanker payudara sebanyak 14 kasus. Eksplan diambil dari spesimen hasil operasi dan ditanam dalam medium kultur 3 dimensi yang telah diberi endhotelial cell line. Aktifitas angiogenesis dinilai secara semikuantitatif invitro. Pengamatan aktifitas angiogenesis dilakukan setiap 24 jam dengan menilai migrasi sel endotel selama 96 jam. Pengamatan didokumentasikan dengan memakai skoring 0-4.

Hasil : Berdasarkan evaluasi terhadap 14 kasus yang dilakukan kultur, didapatkan korelasi antara skor angiogenesis dengan TNM (tumor lymnode metastase), grading, dan tipe histopatologi. Kanker dengan grade III, tipe scirous mempunyai nilai skoring (+4), tanpa memandang TNM.

Diskusi : Angiogenesis dapat terjadi melalui beberapa cara yaitu melaui proses tunas atau bukan tunas. Pembentukan angiogenesis meliputi pembentukan jaringan kapiler baru yang merupakan awal pembuluh darah, sedangkan yang bukan melalui tunas angiogenesis meliputi proses menjadi besar, pemisahan, dan penggabungan calon pembuluh darah. Proses bukan tunas memerlukan proliferasi sel endotel untuk membentuk dinding pembuluh darah. Pada penelitian ini tidak ada korelasi antara umur, status menopaus, dan status masa tumor dengan derajat angiogenesis. Hanya pada tipe histopatologi dan yang mempunyai korelasi dengan derajat angiogenesis dengan korelasi koefisien $p=0,019(<0,05)$.
\end{abstract}

Kata kunci : angiogenesis, kultur jaringan, morfologi kanker payudara. (J I Bedah Indones. 2007; 35(2): 38-41)

\section{Correlation of Angiogenesis with Morphological and Clinical Patterns of Breast Cancer in Tissue Culture}

Abstract

Introduction: Breast cancer can grow, expand and also metastase only if it is provided with nutrition and oxygen. Without blood supply, tumor will be dormant or die. Hence angiogenesis represents the most important factor for cancer cell to grow.

Methods : A cross sectional prospective study was performed on the culture of breast tissue from 14 cases. Angiogenesis activity was assessed semi quantitatively invitro. Explants were taken from surgical specimens and planted in 3 dimensional culture medium which have been seeded with endothelial cell line. The activity of angiogenesis which was represented by endothelial cell migration was observed every 24 hour. After 96 hours this was measured and documented (scoring 0-4). Final observation was done on 96 hour and the result was documented using score 0-4. Results: There is correlation between angiogenesis score with tumor lymnode metastase (TNM), histopathology type, and grading with the exception of grade III i.e., scirus type cancer that is scored (+4) regardless the TNM grade.

Discussion: Angiogenesis activity can occur through either sprouting or non sprouting processes. Sprouting angiogenesis involves the branching of new capillaries from pre-existing vessels. Non sprouting angiogenesis includes enlargement, splitting, and fusion of pre-existing vessels, a process that is mediated by the proliferation of endothelial cells within the wall of a vessel. In this study theres is no correlation between angiogenesis and tumor mass, age, menstruation status. Only histopathology type and grading are significantly correlated with angiogenesis $p=0.019(<0.05)$.

Keywords : angiogenesis, morphology of breast cancer, tissue culture. (J I Bedah Indones. 2007; 35(2): 38-41)

\section{PENDAHULUAN}

Kanker payudara merupakan salah satu penyebab kematian wanita nomor dua yang disebabkan oleh keganasan setelah kanker leher rahim. Di Indonesia kanker payudara ditemukan pada stadium lanjut (III dan IV), sedangkan di Amerika Serikat

Divisi Bedah Onkologi, Departemen Ilmu Bedah, "Fakultas Kedokteran Universitas Diponegoro/RS Kariadi, Semarang; 'Fakultas Kedokteran Universitas Indonesia/ RS Cipto Mangunkusumo, Jakarta ditemukan masih dalam stadium dini (stadium I dan II). Ramli M menemukan sebanyak $23 \%$ pada stadium IIIA (operable), dan $40 \%$ pada stadium IIIB (inoperable). ${ }^{1}$

Observasi secara mendalam tentang bagaimana kanker merangsang pembentukan neovaskularisasi dengan teliti dan 
berkelanjutan, sejak proses onkogenesis sampai terjadinya metastasis jauh, telah meningkatkan pengetahuan tentang proses angiogenesis. Hal tersebut sangat penting untuk mengevaluasi keberhasilan suatu terapi pasien kanker payudara. $^{2}$ Selain itu dapat pula diketahui bagaimana proses awal terjadinya angiogenesis dan implikasinya untuk mengetahui faktor prognostik dan juga prediktif, serta melakukan evaluasi dari pengobatan kanker payudara. ${ }^{2,3}$

Proses angiogenesis merupakan suatu proses yang penting untuk pembentukan jaringan pembuluh darah, dan juga untuk pertumbuhan kanker, invasi, serta metastasisnya. Proses pertumbuhan kanker, invasi dan metastasis berbagai jenis kanker sangat tergantung pada angiogenesis ini. Bahkan tumor padat untuk tumbuh sebesar lebih dari $1 \mathrm{~mm}^{3}$ sudah membutuhkan neovaskularisasi. ${ }^{3}$

\section{METODE}

Disain penelitian ini menggunakan metode observasional dengan pendekatan cross sectional study dengan menilai kualitas angiogenesis secara invitro pada kultur jaringan kanker payudara. Penelitian ini dilakukan secara prospektif pada pasien-pasien kanker payudara yang datang berobat di Divisi Bedah Onkologi RS Cipto Mangunkusumo (RSCM), dengan menilai aktifitas angiogenesis pada kanker payudara secara semikuantitatif dengan menilai gambaran angiogenesis (dilihat setiap 24 jam) dan dilakukan 4 kali penilaian (jam ke-24, 48, 72, dan 96). Hasil gambaran angiogenesis dihubungkan dengan gambaran klinis dan morfologis.

Data yang diperoleh dilakukan analisis dengan uji korelasi Fisher's exact tes dengan menggunakan SPSS versi 15.

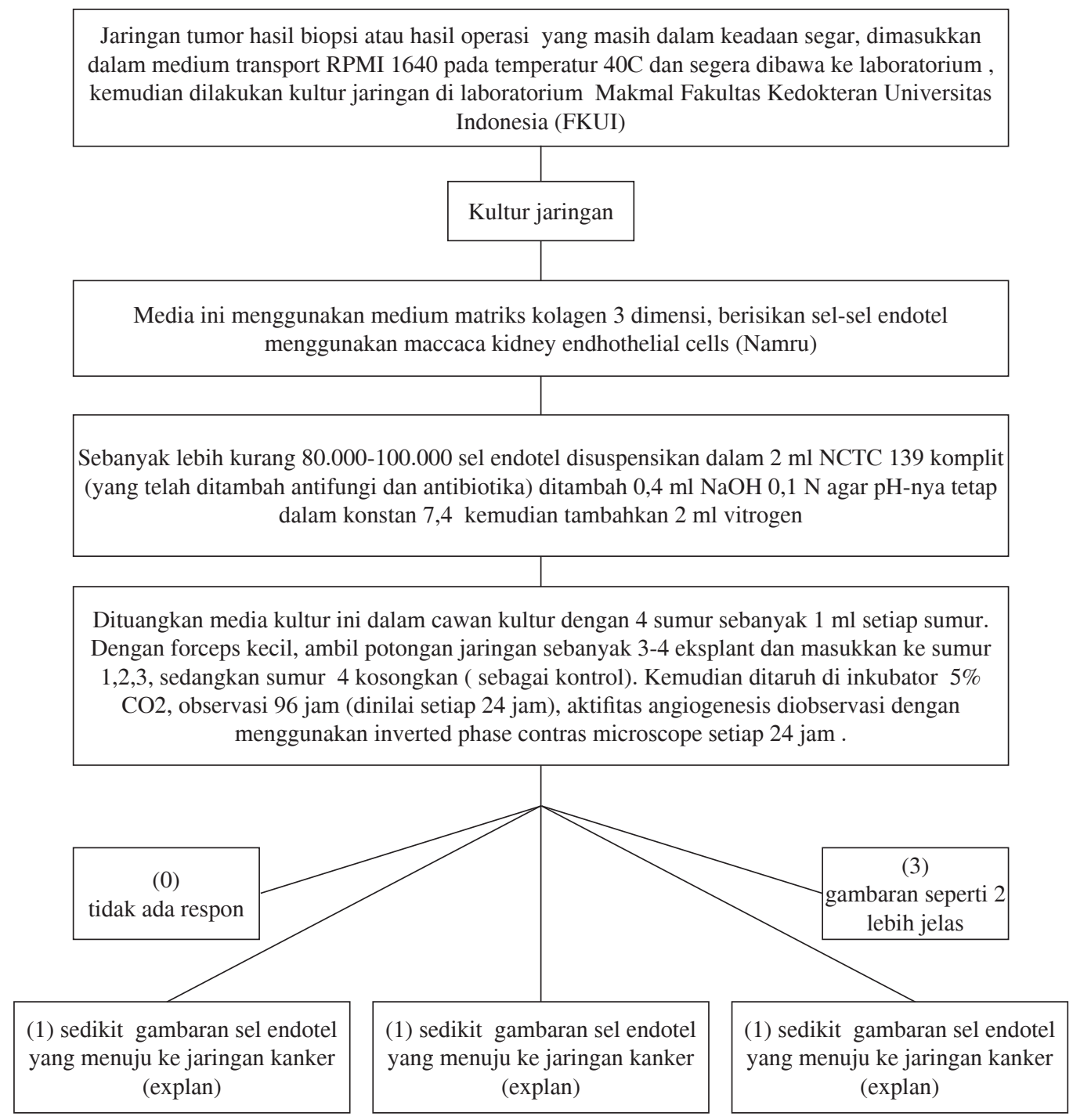

Gambar 1. Alur penelitian 


\section{HASIL}

Tabel 1. Karakteristik subjek penelitian

\begin{tabular}{|c|c|c|c|c|c|c|}
\hline \multirow[b]{2}{*}{ Karakteristik subjek penelitian } & \multicolumn{6}{|c|}{ Angiogenesis } \\
\hline & $\sum$ & $\%$ & +1 & +2 & +3 & +4 \\
\hline Semua pasien & 14 & 100 & & & & \\
\hline \multicolumn{7}{|l|}{ Umur (tahun) } \\
\hline$<40$ & 6 & 43 & - & - & 2 & 4 \\
\hline $40-59$ & 3 & 21 & - & - & - & 3 \\
\hline $60-69$ & 3 & 21 & - & 1 & - & 2 \\
\hline$>70$ & 2 & 15 & - & - & - & 2 \\
\hline \multicolumn{7}{|l|}{ Status hormonal } \\
\hline Premenopaus & 8 & 57 & - & - & 1 & 7 \\
\hline Postmenopaus & 6 & 43 & - & 1 & 1 & 4 \\
\hline \multicolumn{7}{|l|}{ Status massa tumor } \\
\hline Т 0 & 0 & 0 & - & - & - & - \\
\hline T 1 & 0 & 0 & - & - & - & - \\
\hline $\mathrm{T} 2$ & 4 & 29 & - & - & 1 & 3 \\
\hline T 3 & 6 & 42 & - & - & 1 & 5 \\
\hline T 4 & 4 & 29 & - & - & 2 & 2 \\
\hline \multicolumn{7}{|l|}{ Status KGB } \\
\hline N 0 & 7 & 50 & - & - & 1 & 6 \\
\hline N 1 & 5 & 35 & - & - & 1 & 4 \\
\hline $\mathrm{N} 2$ & 2 & 15 & - & - & 1 & 1 \\
\hline N 3 & 0 & 0 & - & - & - & - \\
\hline \multicolumn{7}{|l|}{ Status metastasis } \\
\hline M 0 & 14 & 100 & - & - & - & - \\
\hline M 1 & 0 & 0 & - & - & - & - \\
\hline \multicolumn{7}{|l|}{ Status grading histopatologi } \\
\hline Grade I & 0 & 0 & - & - & - & - \\
\hline Grade II & 9 & 64 & - & 1 & 6 & 2 \\
\hline Grade III & 5 & 36 & - & - & - & 5 \\
\hline \multicolumn{7}{|l|}{ Status tipe histopatologi } \\
\hline Ductal invasive & 14 & 100 & - & 1 & 2 & 11 \\
\hline Solid-tubular & 8 & 57 & - & - & - & - \\
\hline Skirus & 6 & 43 & - & - & - & 6 \\
\hline
\end{tabular}

$\mathrm{KGB}=$ kelejar getah bening

Didapatkan korelasi yang kuat antara subtipe skirus dengan derajat angiogenesis dengan gambaran angiogensis +4 . Tipe skirus dengan nilai +4 , dengan nilai $(p=0,019)$, serta grading histopatologi dengan nilai $(p=0,019)$. Secara statistik nilai $p<0,05$, baik grading maupun subtipe histopatologi mempunyai korelasi yang signifikan terhadap angiogenesis.

\section{DISKUSI}

Kegagalan membunuh keseluruhan sel kanker secara mikroskopis sampai saat ini masih menjadi problem. Hal ini ditunjukkan dengan angka rekurensi sebesar 25\% - 45\% pada 5 tahun pertama pasien kanker payudara stadium dini. Sebagian besar kanker mempunyai respon yang baik terhadap agen sitotoksik yang selama ini digunakan, akan tetapi perlu strategi baru untuk mencapai keberhasilan yang tinggi. Melalui pemahaman tentang patogenesis kanker payudara terutama mengenai proses angiogenesisnya maka akan membuka peluang untuk ditemukannya terapi yang baru. ${ }^{8}$
Dengan melakukan transfection sel tumor menggunakan stimulator peptide angiogenic akan terlihat kenaikan pertumbuhan sel tumor, lebih invasif, dan metastasis. ${ }^{4}$ Pada penelitian ini dari 14 kasus yang diteliti ditemukan stadium II(29\%), stadium III(61\%), pramenopaus $57 \%$, dan pascamenopaus $43 \%$, umur $<40$ tahun $(43 \%)$. Melihat hasil ini maka umur penderita kanker makin muda dan stadium pasien kanker saat didiagnosis mengalami penurunan dibandingkan temuan Ramli M. ${ }^{1}$ Didapatkan korelasi yang kuat antara subtipe skirus dengan derajat angiogenesis. Tipe skirus mempunyai nilai +4 dengan korelasi koefisien $(p=0,019)$, serta grading histopatologi dengan korelasi koefisien $(p=0,019)$. Maka secara statistik dengan $p<0,05$, baik grading maupun subtipe histopatologi mempunyai korelasi yang signifikan terhadap angiogenesis.

Dalam studi ini semua 14 kasus adalah tipe karsinoma duktus invasif, dengan subtipe solid tubular 57\%, dan skirus 43\%. Menurut WHO (Worlds Health Organization), tipe karsinoma duktus invasif digolongkan dalam 3 subtipe yaitu karsinoma papilotubular, solid tubular, dan skirus. Dari subtipe ini derajat defrensiasinya dapat ditentukan 1) subtipe karsinoma papilotubular berdefrensiasi baik, 2) solid tubular berdefrensiasi sedang, dan 3) skirus (berdeferensiasi buruk). Pada subtipe skirus sel tumor melakukan invasi di dalam stoma secara ektensif, terdiri dari kelompok-kelompok kecil yang tumbuh difuse dan infiltrasi ke stroma. ${ }^{5}$

Gambaran klinikopatologi juga mempunyai hubungan yang penting antara angiogenesis dengan progresifitas pertumbuhan kanker payudara. Lesi fibrokistik yang mempunyai densitas vaskular yang tinggi mempunyai hubungan dengan tingginya risiko untuk menjadi kanker payudara. Dengan pemeriksaan micro vessel density (MVD) akan memperlihatkan gambaran histopatologi karsinoma duktal insitu yang agresif juga mempunyai ekspresik VEGF (vascular epithelial growth factor) yang tinggi. Dengan MVD yang tinggi pada invasif disease mempunyai korelasi dengan kecenderungan untuk metastasis dan pendeknya desease-free dan overall survival . ${ }^{6}$

Tumor akan merubah keadaan untuk terjadinya angiogenesis dengan berbagai variasi tergantung stresornya, yang dimulai dari pertumbuhan tumor sampai metastasis. Secara umum tumor tidak akan dapat tumbuh diatas ukuran 1-2 mm tanpa didukung pembentukan angiogenesis. ${ }^{7}$

Maka dengan pemeriksaan tingkat angiogenesis dapat dijadikan sebagai marker prognostik yang independen, karena sel vaskular endote secara genetik lebih stabil pada sel tumor dibandingkan dengan sl normal,dan ini merupakan target terapi yang menjanjikan dalam pengobatan kanker. Angiogenesis yang sering terdapat pada neoplasia akan melibatkan berbagai faktor pendukung diantaranya: vascular endhotelial growth faktor (VEGF), basic fibroblast growth faktor (b FGF), interleukin (IL)-8, dan beberapa proangiogenik faktor lainnya. ${ }^{9}$

Pengetahuan tentang mekanisme molekuler dan regulasi 
pertumbuhan sel kanker, baik meliputi nutrisi dan fungsi sel endotel, kedua komponen ini merupakan bagian terpenting pembentukan angiogenesis. Oleh karena itu bagaimana menghambat kedua proses ini merupakan strategi yang kritis untuk pengobatan kanker. ${ }^{10}$

Dari hasil pengamatan yang dilakukan pada kultur jaringan kanker payudara, didapatkan bahwa dengan cara memahami angiogenesis akan menjadi pijakan pertama untuk melangkah lebih lanjut tentang proses angiogensis. Pemahaman yang baik tentang angiogenesis akan mendorong pencarian pengobatan kanker dengan model secara kultur jaringan, dan merupakan suatu harapan besar dalam terobosan pengobatan kanker di masa mendatang. Tidak tertutup kemungkinan ditemukan obat dari Indonesia yang mampu untuk menekan terjadinya angiogenesis.

\section{SIMPULAN}

Pada penelitian ini didapatkan korelasi yang kuat antara variabel jenis histopatogi dengan derajat angiogenesis. Baik grading maupun subtipe mempunyai korelasi yang signifikan terhadap angiogenesis.

\section{DAFTAR PUSTAKA}

1. Ramli M. Kanker payudara, deteksi dini dan penatalaksanaan masa kini. Paper presented at: Muktamar V/PIT XII, Peraboi; Surabaya, 2000. (Unpublished)
2. Schneider BP, Miller DK. Angiogenesis of breast cancer. J Clin Oncol. 2005; 23:1782-90.

3. Gasparini G. Prognostic value of vascular endothelial growth factor in breast cancer. Oncologist. 2000; 5 Suppl 1: 37-44.

4. Miller K, Sledge GW. Dimming the blood tide: angiogenesis, antiangiogenic therapy and breast cancer. In: Nabholtz JM, editor. Breast cancer management application of clinical and translational evidence to patient care. 2nd ed. Philadelphia, PA: Lippincott Williams \& Wilkins; 2003. p. 287-308.

5. Mirshahidi RH, Abraham J. Breast cancer. In: Abraham J, Allegra JC, Gulley J, editors. Bethesda handbook of clinical oncology. 2nd ed. Philadelphia: Lippincott William \& Wilkins; 2005. p.155-72

6. meRajendran JG, Krohn KA. Imaging hypoxia and angiogenesis in tumors. Radiol Clin North Am. 2005; 43(1): 169 - 87.

7. Gasparini G, Toi M, Gion M, Gion M, Verderio P, Dittadi R, et al. Prognostic significance of vascular endothelial growth factor protein in node-negative breast carcinoma. J Natl Cancer Inst. 1997; 89(2):139-47.

8. Folkman J. Tumor angiogenesis: therapeutic implications. N Engl J Med. 1971; 285: 1182-6.

9. Hwang R, Vamer J. The role of integrins in tumor angiogenesis. J Hematol Oncol Clin N Am. 2004; 18: 991-8.

10. Fidler JI, Ellis ML. Neoplastic angiogenesis not all blood vessels are created equal. N Engl J Med. 2004; 351(3): 215-6. 